\author{
Nataliya Yudina, \\ PhD (Economy), Laureate of the Prize of the President of Ukraine for young scientists, \\ Associate Professor of the Industrial Marketing Department, \\ National Technical University of Ukraine "Igor Sikorsky Kyiv Polytechnic Institute" (Kyiv, Ukraine)
}

\title{
METHODS OF THE STARTUP-PROJECT DEVELOPING BASED ON ‘THE FOUR-DIMENSIONAL THINKING' IN INFORMATION SOCIETY
}

The problem of the human disorientation under the conditions of the information society was analyzed in the article. It was investigated that this problem grows worse on the enterprises' level in order of the consumers' indifferentism to the marketing tools and also in order of the creation of the startup-projects that are used by the business to survive in the economic crisis. The methods of the startup-project developing were proposed that makes enterprises to economize their intellectual assets. It improves upon and adopts the traditional strategic planning and decisions making process to the specific features of the startup-project developing under the conditions of the information society, particularly the information overload. The detalization of each stage of startup-project developing and practical guidelines were developed. The author's model of the "four-dimensional thinking" was proposed that was developed for the first stage of the startup-project developing process as the effective way to adapt the startup-project developers to the information society. That makes it possible to formalize the process of searching and creating of the innovative ideas to the methodological guideline of the practical recommendations. The author's model of the "four-dimensional thinking" allows the information management efficiency to rise up by orienting it in order of the four vectors of dimensions and directions, namely; the thinking in the plane of the interdisciplinary information; the thinking in the time dimension (the "historical filter" and the "futurological filter"); the thinking in the "discipline vertical" dimension of the traditional knowledge and the innovations.

Keywords: informational chaos, chaos control, four-dimensional thinking, information society; information management, startup, startup-project.

DOI: 10.21272/mmi.2017.3-23

Introduction. Emerging of the information society has been evocated by rapidly developing and scaling of information and communication technologies (ICT) in the global world. But explosion of information around the people can lead them to an information overload under these conditions consequences of which can become "future shock". The term "future shock" or fear of the future means a human psychological reaction by way of being under a great deal of stress and disorientation in retaliation for radical changes in very short period of time in environment around a person [1]. So a speed of information explosion, its changes and updating, complicating of the data check verification process can overload the human brain possibilities and resources. Exceeding volume of information has transformed the information value in the information society. In contrast to the industrial society where it has been valuable for a market entity to get access to the specific information, it is valuable to manage Big Data in the information society where information is widely available by ICT. That is why information management tools' developing is one of the most important issues under conditions of the information society that can prevent information overload and future shock.

From a level of a particular enterprise this problem aggravates in two directions. On the one hand this concerns customers that are indifferent to marketing communications in information chaos that leads to loss of the traditional marketing tools effectiveness. On the other hand the problem concerns a marketing department level where its workers have to prepare different management decisions effectively on the basis of a raft of messy information (Big Data). It is particularly topical under conditions of an economic crisis when enterprises try to implement many innovations and wide range of startups to 
survive and overcome ramifications of the crisis.

Analysis of recent research and publications and the emphasis of unsolved aspects of the general problem. Historical currents in particular the economic crisis and economic health of Ukraine at whole have created a background for developing of ventures entrepreneurship [2] that means enterprises to transfer from constant establishment operations and activity to project activity. Project activity is related to a high risk of innovation entering in the market that is made by conducting of researches and sometimes outdoor investments. It can be explained by risks of mismanagement and financial losses (particularly if it means the long term period of time) that are growing under conditions of uncertainty. That is why it's very important for the Ukrainian enterprises to make as more as possible trials in short term periods of time to search an effective order of activity (because it means costs advantages and less financial risks if something is wrong).

So the project activity is related with a kickoff of "startup-projects" other on the basis of already existing enterprises or by the way of setting up new small and mobile businesses (among other things on the basis of big enterprises additionally). Significantly, from doers' point of view the term "startup-project" ("startup" or "start up) means any innovative business area. But it's really too difficult to draw a distinction between a new small enterprise (because it's a new business area for its founder) and an innovative project on the basis of the existing enterprise, particularly if this enterprise introduces an exclusive innovation to the market. The area of innovations at whole and management of startupprojects as its part are developing by Illiashenko S.M. [3; 4], Illiashenko N.S. [3], Bilovods'ka O.A. [4], Glushchenko L.D. [2], Piliavoz T.M. [2], Pererva P.H. [5], Maslak M.V. [5], Kosenko O.P. [6], Petrenko V.A. [7], Dem'ianenko N.G. [7], Kriukova A.A. [7], Novikova M.M. [9], Borovyk M.V. [9], Dinkgreve M. [8], Denn M.M. [8], Bonn D. [8] and many other sciences. All authors create view of innovative processes and ways of management of them. But there isn't a uniform definition of what the term "startup" is yet. So then we'll use the term "startup" as a new enterprise or its new business area that can rapidly be scaled and give high financial profits in a short-term period of time. Such approach is widely used by providers of startup-projects contests with the involvement of international investors.

According to this definition, ventures entrepreneurship needs such enterprises managers to manage their activities by an orthogonal way: the managers have to forget about the constant establishment operations and activity and cross over to the project activity (the startup activity). But under conditions of the information society startups developers also face with one of the most important characteristics of the information society - the problem of Big Data management that is important for startup developing. Most authors agree with the point of view that the main task of management of information for the innovation development is to create new knowledge. So then we'll keep our mind on this way because it's important for startup-project developing.

In these conditions existing traditional approaches to innovation developing need to be adapted to special characteristics of the information society, namely to rapidly scaling changes and accumulation of chaotic information that need the marketing departments and enterprises managers not only to be up to speed on in information chaos but have a high speed of making management decisions through rapidly data deterioration. It needs to develop of simple and user-friendly governance of chaotic information in the information society that can be present by a step-by-step guideline.

The objective of the paper. On the basis of abovementioned the objective of the article is to create a step-by-step governance guideline of developing a startup-project under the conditions of the information society.

The main results of the study. According to the traditional definition, chaos means a disorder and a confusion that haven't any structure or subsequence [10, p. 702]. It leads reference points, principles of general application, norms, criteria, fidelity information assessments to disappear. Under the theory of generations [11] the one of the special features of a new Z-generation which representatives were born 
in the information society and couldn't see their life without ICT is a personality problem of self-definition in the life and society through Big Data of chaotic information [11, p. 36; 12]. The representatives of the other generations of the information society also feel such information disorientation.

In accordance with the social proof principles the criteria of right behavior of a person in a specific environment in specific time is behavior of the most other people [13, p. 113-156]. It makes people behavior without particular reference points to be vulnerable to external governance that leads to replicating and cloning specific behavior at multiple levels of the society but it can beforehand be wrong or even have unpredictable effects. For example, the root ideas of selfie popularization by showbusiness stars (and latent promotion of advanced options of smartphones, life-styles, beauty saloons, restaurants and so on by their brands) have led to mass scaling of selfie-dependency with all its negative consequences. In this context under the conditions of the global availability of information the abstract idea "most of people" have dissolve boundaries. That is why it can lead person to disorientation and information overload. It needs to create some specific road maps and reference points that could be set upon chaotic information area and give the person to develop but not be hung up and cycle. Because the cycling process without developing can be compared with groping in the dark when unorientation provokes resetting, loss of time, means degradation, is detrimental to the whole effectiveness of exploitation of resources of people life and society.

Innovative markets which startup-projects are focused on are characterized by unstructured information and that is why they need prudent using of intellectual assets of employees of the enterprise as all ordinary people are ready to go under the influence of the features of the information society. So developing management decisions about startup has to be presented in more structured form. Management startup-project decisions making means selecting one of alternative ideas of the startupproject and has "to program" all of next actions of the startup-project developers and their team that corresponds fully to all classical traditional process of management decisions making [14, p. 195-196]. Main phases of startup-project developing and its realization are coherent with main steps of this classic making management decisions process, namely there are the researching phase, the phase of strategy planning, the phase of their realization and the phase of the appraisement of their effectiveness. The creating and the realization of the startup-project are characterized by some features. Hereafter this traditional management decisions making approach will be adapted to these features of the startupprojects. Let's take a closer look at these features.

Begin with the two main approaches to the classical formalization of making management decisions about the startup-project developing can be separated [15]. According to the first approach to the process of making decisions the startup-project developing is made on the basis of its developers' intuition and feelings and doesn't include a preliminary analysis and accumulation of marketing information. It means that this approach fits into the aprior approach group. In general such kind of developing and realization of the startup-project is based on own life savings of its developers and doesn't suppose an outsourcing of financial supports because of investors need more detailed information (by the way existing of particular marketing information is one of the essential requirements to forming documentations at contests of the startup-projects). However, such kind of the startup-project management increases its risks because of subjectiveness of the human factor that increases likelihood of mistakes or missing opportunities.

An other approach called the aposterior approach is more appropriate and less risky for startupproject developing because this approach is oriented to an explanation and grounding for necessary financial costs on the basis of the primary background experiences that have been already accumulated by the subject. When it comes to the startup-project developing, that doesn't have own experiencebased data, the startup-project developers can use, for instance, the same data that were already accumulated on the other similar or/and analogical markets by their subjects. According to the aposterior 
approach to making of decisions of the startup-project developing it is a phase of the cycle of the strategic planning. The strategic planning is "a set of actions and decisions proposed by the managers that lead to developing of specific strategies to help the organization to reach own purposes and objectives" [14, p. 256].

In accordance with this approach, the specific features of the startup-project developing and its management mean that it basis on the primary background experiences that were accumulated on the other similar or/and analogical markets in the past. Taking into account primary background experiences, possible future results and retrospective database predictions that have been accumulated by other enterprises is the aposterior approach [10, p. 26; 15]. On this evidence, the startup-project management cannot be considered apart from the planning process because decisions making is its essential part that is associated with other phases of the planning process deeply (Fig. 1).

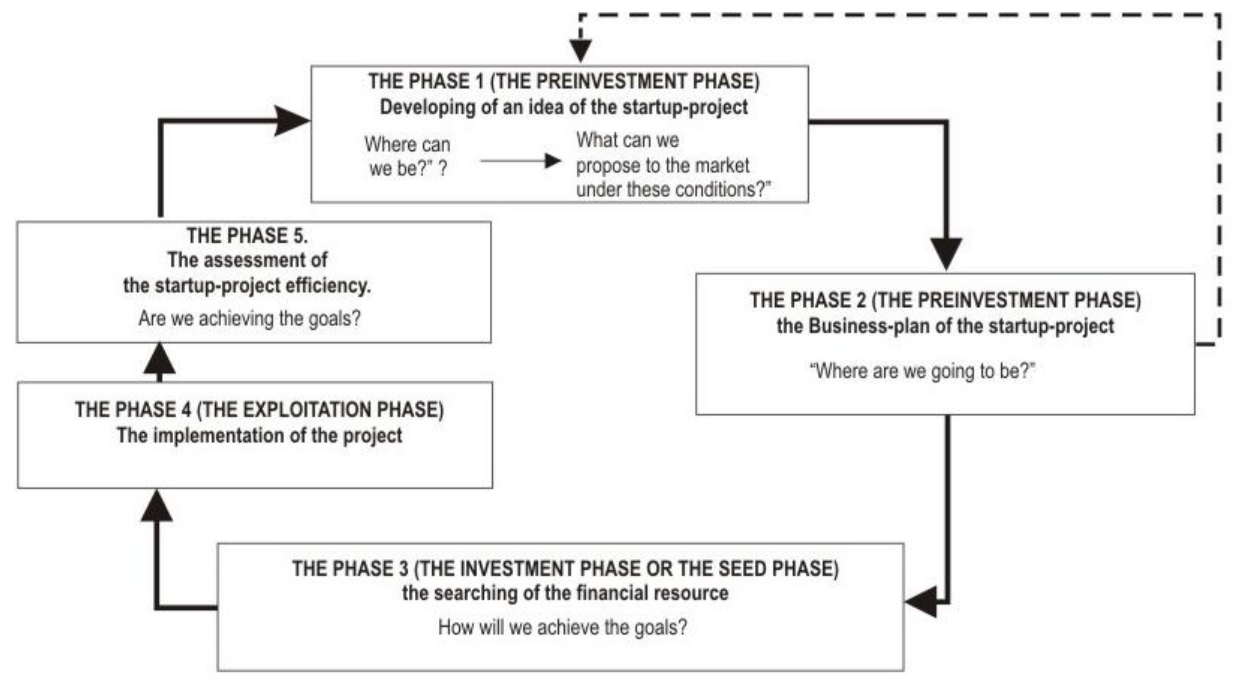

Figure 1 - The aposterior approach to decisions making adapted to the startup-project management [15, fig. 1.14 adapted]

Decisions making is a continuality that consists of the formulation of the alternative decisions hypothesis, their criteria and boundary conditions, testing of the advanced hypothesis and the best decision choice. Function procedures of the startup-project developers with making decisions aren't completed, if the results of its realization aren't known. It is concerned with the function procedures of making the startupproject management decisions as a dynamic iterational process that means continual improving of the innovative activity in accordance with achievements of the startup-project realization and changes in marketing environment. So in accordance with aposterior approach to decisions making, there are the five phases of the startup-project developing that we have adapted to startup-project features: 1) the preinvestment phase of developing of an idea of the startup-project; 2) the preinvesrment phase of the developing startup-project business-plan; 3) the investment phase or the seed phase of the searching of the financial resource; the exploitation phase of implementation of the project; 5) the phase of the assessment of the startup-project efficiency (Fig. 1). The aposterior approach is based on marketing researches at almost all of the phases of the startup-project developing and its realization that make it possible to answer on the closed sequence of five basic questions [16, p. 68] that are also presented at the 
Fig. 1. They make it possible to be out of mismanagement, ineffective and extremely costly decisions and resource spends. Then we'll consider and spell out the feature details of each phase.

The Phase 1 (or the preinvestment phase of the startup-project, an alternative term - the preseed stage) Developing of an idea of the startup-project. Nevertheless the first phase is concerned with the preinvestment stage it has to be taken into account that the phase of developing of the startup-project idea needs the startup-project developers to invest their own time and efforts into it. The Phase 1 that is concerned with searching and forming an startup-project idea is related with a wide range of discussing (sometimes in a "kitchen table" form as it is common called) to take a relevant decision about the startup by its founder. This phase means creating ideas of the startup-project. Let's describe each part of it.

In the preinvestment phase of the startup-project developing the founder pursues answers to questions like "Where can we be?" and "What can we propose to the market under these conditions?" it means to undertake marketing researches for answering to such questions. Significantly that under the conditions of the information society a radical departure from conventional practice of approaches to searching the startup ideas and a new mindset can be more effective. We developed a special author's model of creating innovative ideas and propose to call it "a four-dimensional thinking" hereinafter. It should be noted that the human development stage is entering at the "blow-up regime" that assumes that all of the human processes have picking up speed in accordance with the exponential law [17]. It means that all of the processes in regard to market relationship building are picking up speed yet more. On the one hand such situation leads the traditional tools of management to become antiquated and date, on the other hand it leads to self-cloning of the management decisions yet more. The suggested author's model of four-dimensional thinking means the analyzing of chaotic information structurally in order of four dimensions, namely:

- the "chaotic" thinking broadwise through interdisciplinary economy industries and sciences (an association of the two dimensions - the two-dimensional thinking);

- the thinking in the time-dimension (the third dimension);

- thinking in vertical direction of the specific disciplines (the fourth dimension).

The term "chaotic" thinking broadwise means a special part of the four-dimensional thinking that seems to be more effectiveness for people to adapt themselves to the conditions of the information society thanks to their capability of quickly generating of innovations, sifting ineffective decisions and operational grounding of currently central decisions under the certain situational conditions. Let's take a closer look at the suggested approach that includes next three stages.

The Stage 1. The "chaotic" thinking broadwise means a mindset on a two-dimensional plane of interdisciplinary links (an association of the two dimensions - the two-dimensional thinking). This Stage tries to accumulate a wide range of separate freestanding facts, events, processes, occurrences from different part of the sciences, countries, walks of life (the process of synthesis) (Fig. 2). The chaos of thinking by broad-wise can be compared with some concurrent processes that the enterprise tries to implement to find an effective order of its future long-term activity. The Stage 1 means to associate and mix different and uncorrelatable parts of information together to create a new knowledge (for instance, as "F"-segment that was created on the basis of "A", "B" and "C" segments of knowledge on Fig. 2). That result of it can be without effect for many times but the efforts with the chaotic associating of the different interdisciplinary links together can help to create unpredictable amazing knowledge.

The four-dimensional thinking on the Stage 1 (the two-dimensional thinking) has to be easy to be "installed" (the term is proposed in accordance with software that means to be installed on some computer devices) on "mosaic thinking" that already exists in mindsets of people in the information society. The "mosaic thinking" is characterized by forming not deep but wide knowledge about all different areas of life in the mind-sets of people. In particular such widespread knowledge is formed by acquired habits of outcome monitoring of the news portals and the social medias. It gives the way to 
connect the interdisciplinary links together for creating a new knowledge that is in the borderland between some uncorrelatable areas of life. That is why the main task of the four-dimensional thinking is to set effective management of chaotic information (Big Data) that was accumulated in consciousness and unconscious of the person thanks to "mosaic thinking".

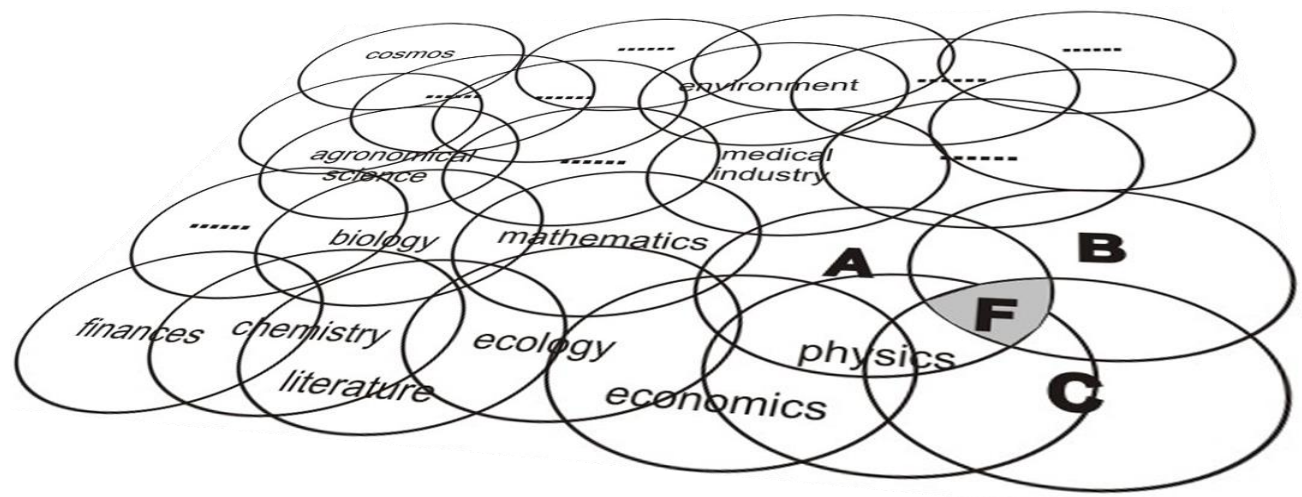

Figure 2 - The Stage 1: the "chaotic" thinking broadwise on a two-dimensional plane of interdisciplinary links.

The marketing analyses approach [18, p. 35-47] can be bestead at the Stage 1. It can be possible to reach all of the important issues of the global economy level that ensure a necessity of the interdisciplinary knowledge that is separated on the Stage 1. Then the SWOT-analysis (for instance, see $[16, p .51])$ had to be conducted on the basis of the results of this global marketing analyses to create a new interdisciplinary innovative project by associating and combining different kind of information (the synthesis process).

The Stage 2 is simultaneously conducted with the Stage 1 because the thinking in the timedimension (the third dimension) ensures the two-dimensional thinking on the Stage 1. This third dimension means analyzing every interdisciplinary innovative project that has been marked as advanced on the Stage 1 by infiltrating with two "time filters": the historical filter and the futurological filter.

The "historical filter" is an analysis of historical events of all parts of the interdisciplinary project (the historical order of time). The result of historical filter using ensures the startup-project developer to define some trends in developing. For instance, the historical filter in marketing of innovations field means constructing of a trend diagram of the markets that are going to be associated to create an innovation, their consumers' behavior during the economic crisis in the past, durations, reasons and consequences of the market downturns from the historical point of view. The historical filter defines trends of event behavior under the conditions of changes of factors in marketing environment. For instance, if our new startup-project idea " $F$ " on Fig 3 has been created by associating and mixing together industries " $A$ ", " $B$ " and " $C$ ", we have to investigate each dynamics of markets " $A$ ", "B" and " $C$ " in the past including the economic crisis periods (Fig 3). It makes it possible to associate such trends together and infiltrate them by the "futurological filter" (the long-term order of time of the future) by the way of the long-term project prediction and the long-term process analysis of the practical implementation of this interdisciplinary project, its future results and consequences (see $F_{\text {(forecast) }}$ on Fig 3). The practices of using of the futurological filter in the analysis of the innovative project that is based on interdisciplinary knowledge is in accordance with the futurological approach to management that is very important to fend off any negative consequences under the conditions of total technologization of the information society. 
The complex thinking process of the Stage 1 and Stage 2 is iterational. For example, sometimes the innovative interdisciplinary knowledge can be regretted and cannot be implement in practices if the predictions of its future consequences are negative. It means the founder to have to return at the Stage 1. However, the Stage 2 is also multilayered thanks to some potential advanced and forwardlooking interdisciplinary associations that can simultaneously be separated at the Stage 1.

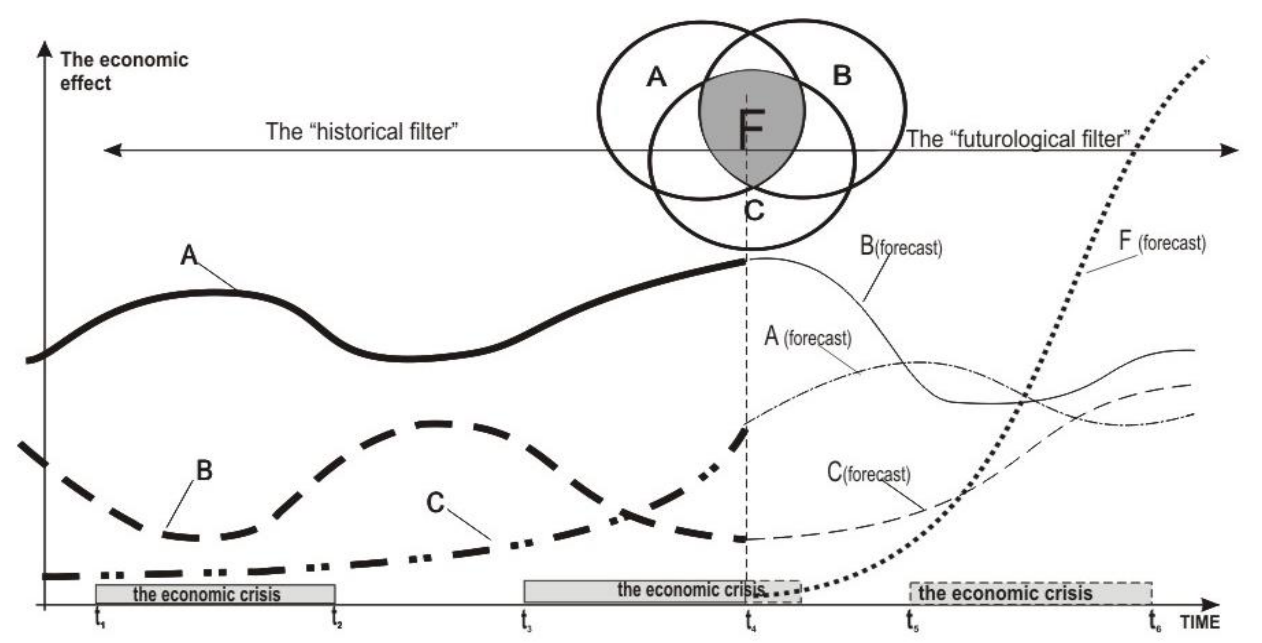

Figure 3 - The Stage 2: the thinking in the time-dimension.

The Stage 3 means thinking in vertical direction of the specific disciplines (the fourth dimension) that supposes the new interdisciplinary knowledge that has been marked as advanced on the Stages 1 and 2 to be checked by infiltrating with the "disciplinary filters". These "disciplinary filters" of studying basic background traditional knowledge (the thinking in vertical direction "into the depth") are the basis of its component parts but they haven't been paid attention enough at the Stage 1 and Stage 2 through the importance of preliminary grounding of the new interdisciplinary knowledge (Fig. 4).

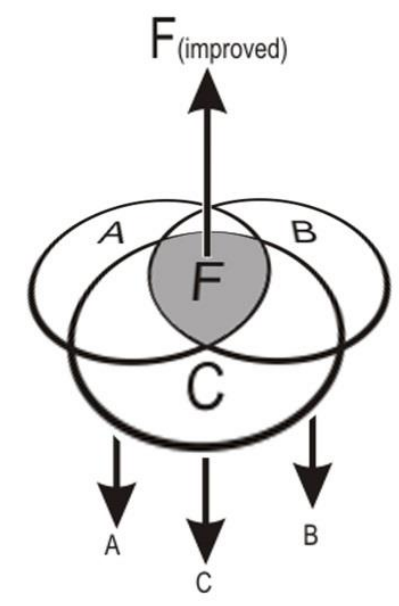

Figure 4 - The Stage 3: the thinking in vertical direction. 
The result of "into the depth" studying of each component part of the new interdisciplinary knowledge provokes improving of the innovation that has been formed at the Stage 1 and Stage 2 (see $F_{\text {(improved) }}$ on Fig 4). It means the process of an upbuilding (the thinking in vertical direction upward). It's important because any innovative knowledge is based on the traditional grounds.

The Phase 2 (the preinvestment phase) the Business-plan of the startup-project (see Fig. 1). The Phase 2 is also a part of the preinvestment phase. It means formulating of detailed answers to the question "Where are we going to be?" and it's the process of making decisions of separating futureoriented advanced ideas, their grounding, strategies of the startup-project realization for some period of time, a complex of purposes of the startup-project founders that are presented in the form of the business-plan. This Phase means the business-plan to be written for finding investments (when outside investments are necessary) and also for grounding the startup-project founders that it is potentiallyenable to be real and achieve the desired result. The business-plan of the startup-project has to be presented to its potential investors to involve outside investments).

The business-plan of the startup-project includes preparing documentations for its potential investors that will finance the startup-project. There are no strict accesses areas or restrictive limitations to a structure of the startup-project business-plan apart from some investment contests, contests of innovative projects or investment programs that have the stringent form of such documents. It is widely acknowledged that the business-plan of the startup-project has to include a comprehensive detailed description of the process of the startup-project practical implementation and have detailed answers to the five basic questions in accordance to the "5W"-principle, namely:

1) "What?" "Who?" For instance: What is the main idea of the startup-project? Who is the potential target audience of the customers? Who are the members of the founders' team and those who will manage the practical implementation of the startup-project? So on.

2) "Why?" For instance: Why will such startup-project have to make the target audience and the market to be interested? Why will this specific feature be the main advantage compared with the competitors? And so on.

3) "Where?" For instance: Where will the startup-project be implemented? Where will the potential consumers receive information about the products and secrecies of the startup-project? Where will the points of sale be located? So on.

4) "When?" For instance: When will the founders of the startup-project reach the breakeven point? So on.

5) "hoW?" For instance: How will the startup-project be implemented? How will the startup-project be commercialized? How will the future profits be distributed? So on.

The Phase 3 (the investment phase or the seed phase of the startup-project) - the searching of the financial resource. In the third Phase answers to question "How will we achieve the goals?" are very important to appreciate, choose and concretize ways of achieving strategic goals that have been defined in the preceding phase. In the third phase of the startup-project the developers have to search financial resources (a seed capital in accordance with the business-plan) to enter the startup-project in the market. It's important for the startup-project developers to take part in wide range of different projects and events that can ensure the meeting with potential investors. There are many events, contests, festivals of the innovative projects, international conferences, exhibitions, forums. But even the ordinary participation in the startup-project contests (even without winnings achievement) can ensure the effectiveness because all of the information about the participants of such events is available on the web-platforms of the organizers in the internet. It ensures the permanent link for a wide range of the potential concerned parties to get a pass for the archives of the startup-projects information. It's also very important for the developers to spread the information about their startup-project in the special crowdfunding platforms widely by themselves for searching resources of the financial assets. 
In the Phase 3 after the founders have found the resources of the financial assets it's very important to pay attention on the questions of law and the judicial documents between the founders and the investors to prevent a discretionary interpretation and potential lack of understanding in the future. It's considered that one of the advantages of the Ukrainian startup-projects is their low-cost compared with analogous startup-projects of the western scientists. But the investors want to get all of the intellectual property rights by the buying of the startup-project. It means that Ukraine will lose its intellectual assets and its future profits if the startup-project is onwards and upwards abroad. But if the startup-project is effectiveness outside Ukraine, the profits will have to return in Ukraine with royalties. It will boost welfare of not only a stand-alone startup-project developer (and his or her scientific establishment if they are scientists) but of Ukraine at all. But this question needs to be regulated distinctly. If intellectual assets emigrated ("were evacuated themselves") abroad during the economic crisis of 1991 and 1998, the specific feature of the economic crisis of resent years is a virtual migration of the intellectual assets. Such kind of migrations is supposed that the developers stay in Ukraine physically but they cooperate with foreign companies by being freelancers or on the basis of outsourcing. Ukraine bears the costs of the life of such virtual "emigrant" but the other country will get profits by this emigrant's performance results. That is why it is very important for the startup-project founders to coordinate their activity (special abroad activity) with legal professionals for the executing of the startup-project documents (investment contracts or technology transfer contracts).

If the developers don't find financial supporting their startup-project and interest of the potential concerned parties and the investors for it, they have to return in the previous phase 1 and correct the startup-project idea. But such failure of the startup-project financing in this Phase doesn't mean that the startup-project hasn't a good perspective. It also means that it can be to outgrow the market developing it wants to enter. It can be more efficiently for it to return in this market little later. But at the present-day period of the market developing it has to be corrected in accordance with market requirements or to choose other idea to implement.

The Phase 4 (the exploitation phase) The implementation of the project. This Phase 4 supposes up four steps of financing of the startup-project depending on the stage of developing and scaling of the startup-project. Each of these stages needs to be detailed written in the investment contract. This separation of the investment contract amount in some parts is necessary because of high risks of the startup-project failures that are possible at any step of its developing. For example, on the first step the investors can finance the additional marketing researches, a closing phase of the development of the innovative product, the additional scientific studying and approbation, test marketing. It affords an opportunity to the investors to be ensured of the prospective of the startup-project business-plan proposed by its developers. The second step supposes the financing of the startup-project entering in the market. It should be noted that only a little number of startup-project finish it because of the high risks of venture entrepreneurship. If the startup-project project kick-off is successful, at the third step of financing it is directed in order of growing and scaling. The fourth step (if all of the previous three steps are successful) financing is directed in order of preparing shares to sale on the stock exchanges.

The Phase 5. The assessment of the startup-project efficiency. In the Phase 5 marketing researches make it possible to compare the startup-project results with the results received at the previous phases. Sometimes the assessment of the experimental results that have been received in the past need to be reconsidered to correct the effectiveness of the startup-project and mean an immediacy of the Phase 5. That is why on the Phase 5 there are the iteration procedures and reverse causality that supposes advancing of the decisions on the basis of the experimental effectiveness. So management of the startup-project activity turns into iteration dynamic process that means continuously assessing by the way of conducting marketing researches of the startup-project effectiveness and correcting it. The effective planned activity of management of the startup-project and grounded strategy are the clear 
direction for working of the team members. It reduces a number of vain efforts, saves time and talent of the creative employees-innovators essentially. All of these are a deficiency and it needs to be used very economically.

Conclusions and recommendations. Under the conditions of the information society the chaotic accumulation of information leads to the information overload people that endanger them by information disorientation. On the level of enterprises that problem becomes more acute in order of developing of startup-projects that are the way for enterprises to survive under the economical crisis conditions. It needed to indent simple and user-friendly for practical implementation governance of startup-project developing under the information society conditions that can lead the person to generate and develop the innovative decisions. So according to aposterior approach to the management, the methods of the startupproject developing were proposed. It improves upon and adopts the traditional strategic planning and decisions making process to the specific features of the startup-project developing under the conditions of the information society. The detalization of each stage of startup-project developing and practical guidelines were developed. The author's model of the "four-dimensional thinking" was proposed to use in the basis of it as it opens opportunities to adapt the process of management decisions making to the information society conditions effectively. As to recommendations to the next research perspectives it needs the practical implementation of the proposed methods of the startup-project developing as in the different kinds of economy industries, as at the level of enterprises, entrepreneurs and researcher-innovators.

1. Тоффрлер Э. Шок будущего : пер. с англ. / Э. Тоффлер. - М. : Издательство АСТ, 2002. - 557 с.

2. Глущенко Л.Д. Венчурне підприємництво як напрямок мобілізації ресурсів ефективної господарської діяльності та розвитку підприємств [Електронний ресурс] / Л. Д. Глущенко, Т. М. Пілявоз // Економічні, фінансово-облікові та правові проблеми Е45 діяльності підприємств : монографія / за заг. ред. Л.М. Савчук. - Дніпро : Герда, 2016. - 336с. - Режим доступу : http://ir.lib.vntu.edu.ua/handle/123456789/14032.

3. Ілляшенко С.М. Перспективи і загрози четвертої промислової революції та їх урахування при виборі стратегій інноваційного зростання [Електронний ресурс] / С.М. Ілляшенко, Н.С. Ілляшенко // Маркетинг і менеджмент інновацій. 2016. - №1. - C. 11-21. - Режим доступу : http://mmi.fem.sumdu.edu.ua/sites/default/files/mmi2016_1_11_21.pdf.

4. Ілляшенко С.М. Управління інноваційним розвитком промислових підприємств : монограффія / С.М. Ілляшенко, О.А. Біловодська. - Суми : Університетська книга, 2010. - 281 с.

5. Перерва П.Г. Венчурна діяльність промислового підприємства та внутрішньо фірмова комерціалізація технологій на засадах інтрапренерства [Електронний ресурс] / П.Г. Перерва, М.В. Маслак // Вісник Національного технічного університету «Харківський політехнічний інститут». - 2016. - №27 (1199). - С. 90-96. - Режим доступу http://repository.kpi.kharkov.ua/bitstream/KhPI-Press/25756/1/ vestnik_KhPI_2016_27_Pererva_Venchurna_diialnist.pdf.

6. Косенко О.П. Комерціалізація інтелектуально-інноваційних технологій : [монографія] / О.П. Косенко. - Х. : Смугаста типографія, 2015. -517 c

7. Петренко В.А. Методологии управления стартап-проектами [Електронний ресурс] / В.А. Петренко, Н.Г. Демьяненко, А.А. Крюкова // Проблемы экономики и менеджмента. - 2017. - №1(65). - Режим доступа http://cyberleninka.ru/article/n/metodologii-upravleniya-startap-proektami. (дата обращения: 29.03.2017).

8. Dinkgreve M. "Everything flows?": elastic effects on startup flows of yield-stress fluids / M. Dinkgreve, M. M. Denn, D. Bonn // Rheologica Acta. - 2017. - Vol.56, No3. - P. 189-194.

9. Новікова М.М. Організація системи управління знаннями [Електронний ресурс] / М.М. Новікова, М.В. Боровик // Матеріали Інтернет-конференції ХНУМГ ім. О.М. Бекетова. - Режим доступу http://ojs.kname.edu.ua/index.php/area/article/view/721/664

10. Ожегов С.И. Словарь русского языка : ок. 57000 слов / под ред. чл.-корр. АН СССР Н.Ю. Шведовой. - 20-е изд., стереотип. - М. : Рус. яз., 1988. - 750 с.

11. Абрамкина М.О. Применение теории Штрауса-Хоува в менеджменте [Електронний ресурс] / М.О. Абрамкина // Экономика и управление: анализ тенденций и перспектив развития. - 2015. - №20. - Режим доступа : http://cyberleninka.ru/article/n/primenenie-teorii-shtrausa-houva-v-menedzhmente (дата обращения: 12.02.2016).

12. Доній Н.Є. Криза ідентичності як контекст розвитку соціальної девіталізації особистості / Н.Є. Доній // Філософія науки: традиції та інновації. - 2014. - №. 1. - С. 178-186.

13. Чалдини Р. Психология влияния = Influence science and practice / Роберт Чалдини. - 4-е междунар.изд. - СПб. Питер, 2006. -288 с.

14. Мескон М.Х. Основы менеджмента : пер. с англ. / М.Х. Мескон, М. Альберт, Ф. Хедоури. - М. : Дело, 1992. - 702 с. 
15. Юдіна Н. В. Управлінські рішення в рекламній діяльності поліграфічних підприємств [Електронний ресурс] : дис. ... канд. економ. наук : 08.00 .04 / Юдіна Наталія Володимирівна. - К. : НТУу «КПІ», 2009. - 270с. - Режим доступу : http://ela.kpi.ua/handle/123456789/346.

16. Джоббер Д. Принципы и практика маркетинга : пер. с англ. : уч. пос. / Д. Джоббер. - М. : Издательский дом «Вильямс», 2000. - 688 с. : ил.

17. Князева Е. Н. Основания синергетики. Режимы с обострением, самоорганизация, темпомиры / Е. Н. Князева, С.П. Курдюмов. - СПб. : Питер, 2002. - С. 38-39.

18. Старостіна А. О. Маркетингові дослідження. Практичний аспект / А. О. Старостіна. - К.; М.; СПб. : Видавничий дім «Вільямс», 1998. - 262 с.

1. Toffler, Ye. (2002). Shok budushhego [Future Shock]. Moscow : Izdatel'stvo ACT [in Russian].

2. Glushchenko, L.D., \& Piliavoz, T.M. (2016). Venchurne pidpryiemnytstvo yak napriamok mobilizatsii resursiv efektyvnoi hospodars'koi diial'nosti ta rozvytku pidpryiemstv [Venture business area as an effective resource mobilization and economic activity of enterprises]. Ekonomichni, finansovo-oblikovi ta pravovi problemy E45 diial'nosti pidpryiemstv - Economic, financial, accounting and legal problems of enterprises E45. L. M. Savchuk (Ed.). Dnipro : Herda. Retrieved from http://ir.lib.vntu.edu.ua/handle/123456789/14032 [in Ukrainian].

3. Illiashenko, S.M., \& Illiashenko, N.S. (2016). Perspektyvy i zahrozy chetvertoi promyslovoi revoliutsii ta ikh urakhuvannia pry vybori stratehiij innovatsiijnoho zrostannia [Opportunities and threats of the fourth industrial revolution and their reflection in the selection of innovative growth strategies]. Marketynh i menedzhment innovatsii - Marketing and Management of Innovations, 1 11-21. Retrieved from http://mmi.fem.sumdu.edu.ua/sites/default/files/mmi2016_1_11_21.pdf [in Ukrainian].

4. Illiashenko, S.M., \& Bilovods'ka, O.A. (2010). Upravlinnia innovatsijnym rozvytkom promyslovykh pidpryiemstv : monohrafiia [Management of innovative development of industrial enterprises: monograph]. Sumy : Universytets'ka knyha [in Ukrainian].

5. Pererva, P.H., \& Maslak, M.V. (2016). Venchurna diial'nist' promyslovoho pidpryiemstva ta vnutrishn'o firmova komertsializatsiia tekhnolohij na zasadakh intraprenerstva [Venture activity of industrial enterprises and domestic proprietary technology commercialization based on entrepreneurship]. Visnyk Natsional'noho tekhnichnoho universytetu "Kharkivs'kyj politekhnichnyj instytut» - Herald of the National Technical University 'Kharkiv Polytechnic Institute', 27 (1199), 90-96. Retrieved from http://repository.kpi.kharkov.ua/bitstream/KhPI-Press/25756/1/vestnik_KhPI_2016_27_Pererva_Venchurna_diialnist.pdf [in Ukrainian].

6. Kosenko, O.P. (2015). Komercializaciya intelektualno-innovaciinykh texnologii [Commercialization of intellectual and innovative technologies]. Kharkiv: Smugasta typografiya [in Ukrainian].

7. Petrenko, V.A., Dem'ianenko, N.G., \& Kriukova, A.A. (2017). Metodologii upravleniia startap-proektami [Methodology for managing start-up projects]. Problemy ekonomiki i menedzhmenta - Problems of Economics and Management, 1 (65). Retrieved from http://cyberleninka.ru/article/n/metodologii-upravleniya-startap-proektami [in Russian]

8. Dinkgreve, M., Denn, M.M., \& Bonn, D. (2017). "Everything flows?": elastic effects on startup flows of yield-stress fluids. Rheologica Acta, 56,(3), 189-194.

9. Novikova, M.M., \& Borovyk, M.V. (n.d.). Orhanizatsiia systemy upravlinnia znanniamy [Organization of Knowledge Management]. Materialy Internet-konferentsii KhNUMH im. O.M. Beketova - Proceedings of the Internet conferences O.M. Beketov KhNUMH. Retrieved from http://ojs.kname.edu.ua/index.php/area/article/view/721/664 [in Ukrainian].

10. Ozhegov, S.I., \& N.Yu., Shvedova (Eds.) (1988). Slovar' russkoho yazyka : ok. 57000 slov [Russion Dictionary : about 57000 words].. Moscow : Rus. yaz [in Russian].

11. Abramkina, M.O. (2015). Primenenie teorii Shtrausa-Houva v menedzhmente [The application of the Strauss-Hove theory in management]. Ekonomika i upravlenie: analiz tendencii i perspektiv razvitiia - Economics and management: analysis of trends and development prospects, 20. Retrieved from http://cyberleninka.ru/article/n/primenenie-teorii-shtrausa-houva-v-menedzhmente [in Russian]

12. Donii, N. Ye. (2014). Kryza identychnosti yak kontekst rozvytku sotsial'noi devitalizatsii osobystosti [Identity crisis as the context of social identity devitalization]. Filosofiia nauky: tradytsii ta innovatsii - Philosophy of science: tradition and innovation, 1 , 178-186 [in Ukrainian].

13. Chaldini, R. (2006). Psihologiia vliianiia [Influence science and practice] (4th international ed.). Saint Petersburg : Piter [in Russian].

14. Meskon, M.H., Al'bert, M., \& Hedouri, F. (1992). Osnovy menedzhmenta : per. s angl. [Fundamentals of Management]. Moscow : Delo [in Russian].

15. Yudina, N.V. (2009). Upravlins'ki rishennia v reklamnii diial'nosti polihrafichnykh pidpryiemstv [Management decisions in advertising printing companies]. Candidate's thesis. Kyiv: NTUU "KPI". Retrieved from http://ela.kpi.ua/handle/123456789/346 [in Ukrainian].

16. Dzhobber, D. (2000). Principy i praktika marketinga [Principles and practice of marketing]. Moscow : Izdatel'skii dom «Vil'iams» [in Russian].

17. Kniazeva, E. N., \& Kurdiumov, S. P. (2002). Osnovaniia sinergetiki. Rezhimy s obostreniem, samoorganizaciia, tempomiry [Foundations of synergetics. Modes with peaking, self-organization, tempos wolds], (pp.38-39). Saint Petersburg : Piter [in Russian].

18. Starostina, A. O. (1998). Marketynhovi doslidzhennia. Praktychnyj aspekt [Marketing researches. Practical aspects]. Kyiv; Moscow; Saint Petersurg : Vydavnychyi dim «Vil'iams» [in Ukrainian]. 
Н.В. Юдіна, канд. екон. наук, Лауреат Премії Президента України для молодих вчених, доцент кафедри промислового маркетингу, Національний технічний університет України «Київський політехнічний інститут імені Ігоря Сікорського» (Київ, Україна)

Методика розроблення стартап-проекту в інформаційному суспільстві на засадах «чотирьохвимірного мислення»

Проаналізована проблема дезорієнтації людини в умовах інформаційного суспільства. Зазначено, що проблема особливо загострюється на рівні підприємств як у напрямку зростання байдужості споживачів до маркетингових інструментів, так і в напрямку розроблення стартап-проектів, метою яких є подолання економічної кризи. 3 метою економного використання інтелектуального ресурсу підприємств запропонована методика розроблення та управління стартап-проектом, яка являє собою удосконалення та адаптацію процесу прийняття рішення до особливостей стартап-проектів, а також специфічних умов інфрормаційного суспільства, а саме, стрімкого зростання швидкості змін і нарощення обсяеу інформації у глобальному світі. Запропоновані деталізація та практичні рекомендації до кожного етапу управління процесом розроблення стартап-проекту. Методика грунтується на запропонованій авторській моделі «чотирьохвимірного мислення», що дозволило формалізувати процес пошуку та створення інноваційних ідей до методичного переліку практичних рекомендацій в умовах інформаційного суспільства. Авторська модель «чотирьохвимірного мислення» дозволяє підвищити еффективність управління інформаиією иляхом спрямування процесу оброблення значного обсягу інформації за чотирма напрямами (вимірами), а саме: площині міждисциплінарних зв'язків; у вимірі часу, що передбачає накладання на інформаацію двох часових «фільтрів» (історичного і футтурологічного); а також у вимірі «дисциплінарної вертикалі», що передбачає поєднання традиційних знань і інновацій.

Ключові слова: інформаційний хаос, чотирьохвимірне мислення, інфформаційне суспільство, управління інформацією, стартап, стартап-проект

H.B. Юдина, канд. экон. наук, Лауреат Премии Президента Украины для молодых ученых, доцент кафедры промышленного маркетинга, Национальный технический университет Украины «Киевский политехнический институт имени Игоря Сикорского» (г. Киев, Украина)

Методика разработки стартап-проекта в информационном обществе на основе «четырехмерного мышления»

Проанализированы проблемы дезориентации человека в условиях информационного общества. Отмечено, что проблема особенно обостряется на уровне предприятий как в направлении возрастания равнодушия потребителей к маркетинговых инструментам, так и в направлении разработки стартап-проектов, иелью которых является преодоление экономического кризиса. С иелью экономного использования интеллектуального ресурса предприятий предложена методика разработки и управления стартап-проектом, которая представляет собой усовершенствование и адаптацию проиесса принятия решений к особенностям стартап-проектов, а также специфическим условиям информационного общества, а именно, стремительного роста скорости изменений и наращивания объема информации в глобальном мире. Предложены детализация и практические рекомендации к каждому этапу управления процессом разработки стартап-проекта. Методика основывается на предложенной авторской модели «четырехмерного мышления», что позволило формализовать процесс поиска и создания инновационных идей до методического перечня практических рекомендаций в условиях информационного общества. Авторская модель «четырехмерного мышления» позволяет повысить эфффективность управления инсормацией путем обработки значительного объема информации по четырем направлениям (измерениям), а именно: в плоскости междисииплинарных связей; в измерении времени, что предполагает наложение на инсормацию двух временным "фрильтров» (исторического и фрутурологического); а также в измерении «дисциплинарной вертикали», что предполагает объединение традиционных знаний и инноваций.

Ключевые слова: информационный хаос, четырехмерном мышления, информационное общество, управление информацией, стартап, стартап-проект.

Отримано 31.03.2017 p. 